\title{
Digital Communication in Post Pandemic Times: Impact on Indian Youth
}

\author{
Ashiqha Sultana ${ }^{1, a)}$ \\ ${ }^{1}$ Academic Associate, Indian Institute of Mass Communication, India \\ a) author correspondence: ashiqha2811@ gmail.com
}

DOl: https://doi.org/10.18196/ikm.12809

\section{Article Info}

Article history: Received 25 Sep 2021 Revised 14 Oct 2021 Accepted 15 Oct 2021

\begin{abstract}
Communication has adapted to various drastic changes during the COVID-19 pandemic. The outbreak of pandemic has forced every form of communication to a complete halt. Connectivity, social-networking, internet advertisements, virtual reality, and video conferencing are no longer optional and have become must-haves. Though COVID-19 is obviously playing a major role as a trigger, the paradigm changes in communication have been emerging throughout. Listening is not easy as before since it has become virtual where some find to balance Indian youth has been greatly affected with the shift taken place during the pandemic and leads the way to the post-pandemic India. The basic question is on how the Indian youth have come across the pandemic times and started looking forward to the new wave in the emerging technological advancements in communication. This research study examines the communication technologies that have emerged mostly during pandemic times and their effect on Indian Youth. The research method used for the study is analytical survey among Indian youth from various Indian cities. The result of the study clearly explains the reception for the communication advancements.
\end{abstract}

Keywords: Communication; Paradigm Shift; Digital Technologies; Social Networking; Indian Youth.

\section{ABSTRAK}

Komunikasi telah beradaptasi dengan berbagai perubahan drastis selama pandemi COVID-19. Merebaknya pandemi membuat segala bentuk komunikasi terhenti total. Konektivitas, jejaring sosial, iklan internet, virtual reality, dan konferensi video tidak lagi opsional dan sudah menjadi kebutuhan. Sementara COVID-19 jelas memainkan peran utama sebagai pemicu, pergeseran paradigma dalam komunikasi telah muncul di mana-mana. Mendengarkan tidak semudah sebelumnya karena telah menjadi virtual dimana beberapa temuan untuk mendapatkan keseimbangan pemuda India sangat dipengaruhi oleh pergeseran yang terjadi selama pandemi dan menuju India pascapandemi. Pertanyaan mendasarnya adalah bagaimana anak muda India menghadapi pandemi dan mulai menantikan gelombang baru kemajuan teknologi komunikasi yang muncul. Studi penelitian ini mengkaji teknologi komunikasi yang muncul sebagian besar selama pandemi dan pengaruhnya terhadap Pemuda India. Metode penelitian yang digunakan untuk penelitian ini adalah survei analitik di kalangan pemuda India dari berbagai kota di India. Hasil penelitian ini jelas menjelaskan penerimaan kemajuan komunikasi.

Kata Kunci: Komunikasi, Pergeseran Paradigma, Teknologi Digital, Jejaring Sosial, Pemuda India. 


\section{INTRODUCTION}

The COVID-19 pandemic has shifted the values and lifestyles profoundly, which has deep and widespread effects on both people and sustainable growth. The widespread economic and social shutdown resulted in reduced ecological impact by cutting downscaling that enabled people to decouple business. To counterbalance the gloom of the global pandemic, one dim light shows how data and digital technologies may be used to enhance hope for the future (Horgan et al., 2020). operation and transportation and permitted more time for family and social connections. Problems of plenty have been exacerbated. There has been a profound impact of digital technology on how people live and study. In fact, many of them have been using digital technology since they were very young children and will continue to be deeply ingrained in it for the rest of their lives (Iivari et al., 2020). Disruptive innovations provide more advanced AI, IoT, the Internet of Medical Things (IoMT), big data, virtual reality (VR), as well as new approaches including self-piloting drones, robotics, and others. All contribute to the potential for digital transformation (Abdel-Basset et al., 2021). The massive technological resources available now puts today's COVID-19 pandemic in stark contrast to the many prior outbreaks.

Digitalization has had a significant impact on global social and economic activity. Information processing through the central route takes place when the recipient evaluates a persuasive message based on critical thinking about the message content (Naryoso, Febriyani, \& Kaloka, 2021). Due to the rapid expansion of the Internet, computers, laptops, tablets, and smartphones during the past two decades, we now live in a "digital" or "virtual" world. People nowadays are able to have new types of communication in order to maintain connections with others. In the wake of the coronavirus shutdown, all the digital platforms and social media were aware of the rise in people's usage of online tools because of the unprecedented digital activity of the population. Communication technologies (particularly the internet) may have a tendency to bridge or disconnect people depending on the circumstances. In face-to-face encounters, a greater number of nonverbal social signals like facial expressions, voice, and touch aid us in conveying information. Because online communication lacks these indications, it results in a more impersonal exchange of information. Similarly, studies show that Internet use and social media are linked to a lower capacity for compassion and an increased tendency to be self-focused.

People who have trouble connecting face-to-face with others are assisted by the assistance they get through digital platforms to preserve relationships. With online communication, individuals believe that they may enhance their current connections with friends and family when in-person social contacts are blocked by lockdown, particularly when people utilise the internet to maintain communication. The COVID-19 issue has highlighted the need for both communication infrastructures and services and access to and rigorous control of data. Providing broadband service to remote and underserved populations in rural and urban areas as well as boosting the local economy by providing them with faster, better fixed and wireless internet may lead to an increase in both economic and social well-being. As more and more businesses and citizens shift towards "going digital" after the COVID-19 issue, governments must promote the skill sets required for employees to thrive in the digital economy and make greater efforts to increase the use among small- and mediumsized businesses (SMEs). Addressing technology-rich problems have well-rounded abilities in reading, numeracy, and problem-solving. Digital innovation is important to the ongoing digital revolution since it helps generate new products and services, helps facilitate new business models, and help realise efficiency in many sectors. Incentivizing additional research and development while increasing business startups may help boost the national response to and recovery from the current crisis.

Although COVID-19 has established an even larger use of digital tools as a result, we must pay even more attention to ensuring that we have faith in the digital environment. In particular, this includes addressing digital security, but also privacy, data, and consumer protection. The outbreak provided criminals with a huge opportunity, and they quickly capitalised on the surge in internet traffic. Despite having funds assigned to them, the majority of grants lack assessment, analytics, and financial autonomy. Businesses and markets already feel the impact of the digital revolution, and they face substantial concerns about the future of employment. Due to the plague, more companies are having people work from home, and there are concerns about whether certain occupations will still exist in the future. This new economy calls for labour market institutions and laws to be examined and corrected while also ensuring that displaced employees are not left behind. 
Vol. 13 No. 2

Due to increased internet use during the pandemic - whether for job, education, or social purposes - individuals require more assistance. In the context of this potential to solve all the varied societal problems the digital revolution presents, governments must lead the way by acting to address the many questions related to data-driven healthcare, misinformation, and screen addiction, among others. Despite the chaos, digital technology will persist and change our lives and work. The IoT and $5 \mathrm{G}$ will drive the current data governance, privacy, and security policy debates even more. Issues that are particular to businesses may become even more prevalent as companies evaluate the costs and advantages of expanding, particularly in manufacturing facilities. In light of the COVID-19 situation, countries must now coordinate internationally to confront complex, interrelated problems that need coordinated, collaborative efforts. The amount of screen time offered during COVID-19 has risen due to government mandates imposed to contain the epidemic. As global communities became more organized, the sole means of keeping socially and emotionally engaged became digital. Though the possible negative consequences on physical and mental health do exist, particularly due to the longterm effects of overuse of screens, the negative implications of social connectedness (e.g., "healthy") warrant strict implementation of healthy digital habits, which will likely be with us for the long term.

As a result of the pandemic, people were cut off from having an active social life and from communicating with friends and family. Due to this, many of them began using digital devices excessively for socialising, including virtual dates, virtual tourism, virtual parties, and family conferences. Ironically, as social distance occurs, screen time can only serve as a method of maintaining social connectivity. While constant digital screen time must be used with caution, we must be aware of its influence on our children. Additional worrying indicators of people's emotional health during the crisis included unusual levels of anxiety, sadness, uncertainty, and negative emotions such as irritation and aggressiveness, which may be linked to the broader societal reaction to the epidemic. But there was a rise in cybercrimes and cyberattacks as well, leading to the emergence of feelings of fear and anger. While digital health tech expanded rapidly, it's also important to pay attention to digital health and well-being, since extended screen time was necessary. Studies from several groups have shown to an increase in screen time driven by COVID-19; however, the results are often found in separate reports.

A novel circumstance arose that required assessing how digital tools performed as substitutes for face-to-face interactions, because the COVID-19 crisis resulted in extraordinary limitations. There is little doubt that the use of communication technology during a lockdown may significantly affect how it seems to people that others are supporting them. That, in turn, can serve as a buffer against the psychological consequences of social isolation. The influence of COVID-19 is instant and farreaching. After months of isolation, people are now beginning to be permitted more freedom, but for the foreseeable future, we will continue to suffer the impact of the coronavirus on our daily lives. Remote working, removing social interaction, and rethinking how businesses use offices and public places will have long-term impacts on what is considered "normal." Many businesses have second thoughts about their physical surroundings as they think about what is coming next and their longterm destiny. This time is better than ever to reconsider the offices. IP video-based technologies are becoming critically important for many people. Online streaming will have an ever-increasing role in organisations with distributed staff, hospitals that need to keep both staff and patients safe, and educational facilities that wish to enable students to learn via digital signage and streaming video.

Indian youth has had a major inclination to the digital world due to COVID. People have begun to see social media as a vital communications platform, both for governments and organisations and for academic purposes. Pandemic has forced the new learning technologies using virtual listening (Itzchakov \& Grau, 2020). The internet has made it easier for process, which is started with the searching (Kencana \& Meisyanti, 2020). Pandemic has created a short-term health problem that manifests itself in obvious ways for all those who see it. Long-range implications for the individual's well-being have not yet been found but may be observed by deciphering relationships with material, social, and mental factors (Echegaray, 2021). As teaching moved online, instructors connected with their students through their personal devices, mostly their smartphones and, on occasion, their home computers or laptops (Iivari et al., 2020). Unparalleled amounts of material are available via social media sites like YouTube and Twitter, propagating disinformation and unverified rumours. Algorithms moderate and promote information dissemination since they are equipped to respond to consumers' want to be informed. There is a substantial impact on social views and how narratives are framed and told, and this is having a major effect on how the government makes policy, conducts political communication, and changes the discourse in the public. When it comes to getting 
information, it is the general belief that people on the internet can be on one side of a story, since they've already got a place in their world view. Additionally, if the polarization is extreme, people may easily be deceived into believing falsehoods. Fake news and false information may travel farther and quicker than truthful information, according to several studies. But it may be a special effect unique to one kind of device. Since political debates frequently use labels like "fake news" to refer to contrary views, the concept of fake news may itself be inaccurate. In addition to looking at the effects of social media on how people see controversial issues, researchers are studying how such issues are perceived on social media. Many publications approach the problems of infodemic in various ways, for instance, the causes people to develop views via disinformation and how to stop people from spreading fake news. Numerous experiments have now used social network data to classify, measure, and analyse infectious disease outbreaks and public opinions, so we would be in a position to make the best predictions possible from now on (Tsao et al., 2021). Continuous Internet surfing and video chatting are replacing many other activities. However, these myriads of positives have accrued from social media.

To begin with, it has made people aware of how important it is to remain connected and exchange knowledge regarding both the physical and emotional aspects of their lives. In the safety of our own houses, it has made us efficient and brought our old acquaintances back into focus. A spike in video chats online sites like Skype has strained family relationships because we can now see our loved ones and friends thousands of miles away. Besides, the widespread use of digitization has opened a new door for citizens to obtain a passive source of income. The lockdown took the entire urban area to a complete halt. Platforms like Netflix and Amazon Prime offered home subscribers all from scratch, provided 'Over the Top' material. This increase was offsetting the general loss of subscribers and occurring almost concurrently with the huge rises in all other segments. All the perks of work from home came to light with time, but working in cities had lost its allure at this stage. By granting workspaces and giving workers a modicum of authority, the authorities also allowed business operations to return to normalcy. There was a significant effect on the average period the whole sector invested on OTT networks because of this. But how these shifts take form depends specifically on the basis of the socio-economic and historical factors that must be part of our understanding and plans of a future beyond COVID-19 (Büscher et al., 2021). In spite of all socio-cultural changes communication technologies have emerged into a different level where people were forced to adapt to the new normal (Grapsa, 2020). People are exhausted emotionally and thus found ways to overcome this. This study examines and explains the new technological advancements which came into major existence during pandemic and will continue to be the major breakthroughs for the coming decade.

In the field of communication theory, "uses and gratification theory" (also known as "need seeking theory") is one of the ideas that focus on social communications. This theory applies a functionalistic perspective to communications and media, and it asserts that an essential job of the media is to meet the wants and motivations of the audience. They engage with and create the material and other users to build virtual communities and social relationships for themselves (Shao, 2009). So, the more these requirements are fulfilled, the greater the level of pleasure that is achieved. This theory focuses on the themes of the audience before moving on to examine both the message and the social structure. In other words, this theory is concerned with how consumers seek media and to what degree they are pleased with the kind, substance, and manner of consumption that they get. It will be possible to identify the good and negative consequences of particular media by answering the two questions posed in "Use and Gratification" as well as the reasons for utilising specific media.

The idea of uses and satisfaction often focuses on the gratifications that arise as a consequence of usage rather than on the aim of using anything in particular. For example, people who are dependent on social media in an emergency want more meaning and self-worth. Compliments affect how often someone uses their product, except for knowledge sharing. It has been determined that there are two distinct kinds of pleasure: "content gratification" and "process gratification." Receiving specific messages is more essential in content satisfaction, while participation in the "use process" is much more vital in process gratification. In the uses and pleasure theory, several models of gratification have been given. The cognitive and cultural models were two of the most significant models provided by MacQuail, and the other models introduced by others (1984). With regard to resemblance to the original uses and satisfaction models, the cognitive model is the most comparable of the bunch. However, it is impossible to ignore the cultural model. Although shared interests and curiosity serve as the basis for the cognitive model, the cultural model incorporates the individual's overall expectations and preoccupations into the equation. 
In this particular study, the researcher analyses the importance of digital communication and how it influenced the Indian Youth to spend screen time rather than interpersonal forms of communication. Throughout the study, the use of digital platforms for various purposes by Indian Youth is being discussed.

Objectives of this particular study are:

1. Examines the growth and use of multiple social networking platforms and its effects.

2. Determine the effects created by OTT platforms

3. Finds out the impact of Virtual Reality, Learning Apps and online gaming.

\section{METHODS}

The research method used for this particular study is analytical survey. An analytical survey attempts to describe and explain why situations exist. In this approach, two or more variables are usually examined to investigate research questions or test research hypotheses. To define and explain why particular circumstances occur, analytic surveys are conducted. Typically, two or more variables are investigated in order to test hypotheses using this method of investigation. Researchers may use the findings to analyse the interrelationships between variables and make explanatory conclusions.

Survey research usually seeks to provide empirical data collected from a population of respondents on a whole number of topics or issues. The basic tool for this research is the questionnaire. It standardizes and organizes the collection and processing of information. Hypotheses of the Study

H01: Indian Youth is highly influenced by social media since COVID-19 lockdown.

H02: Majority of Indian Youth have an inclination towards different forms digital communication post pandemic.

H03: Major percentage among Indian youth has subscribed to the OTT platforms since the inception of pandemic.

H04: Learning apps, online gaming and virtual reality have taken major space among the minds of Indian youth post pandemic.

\section{RESULT AND DISCUSSION}

This study shows a positive shift towards technological advancements that are mainly focused on digital or online services. Survey was carried out among 252 Indian citizens, both male and female, who belong to different age groups and different regions in India. This particular study explains that the younger generation is highly inclined to the digital communication technologies emerged in high degree due to the pandemic. A great number of the respondents in age groups ranging from $20-30$ explore every online communication service daily, including social networking sites and apps since the pandemic. The use of OTT platforms is yet another major advancement among the urban youth in India. Findings show that the subscriptions to the major OTT platforms like Amazon prime video and Netflix have a sudden rise due to the pandemic. Over $60 \%$ of the respondents have subscribed to any one of these platforms for binge-watching. Online Gaming and augmented reality attract most of the youth in India. In many colleges and secondary schools around the globe, there has been a change from classroom-based to online virtual education and the integration and hybrid environments.(Jamalpur et al., 2021) Thus, most of the respondents already adapted to the new learning technology where communication shifted from traditional to digital/virtual.

\section{Indian Youth is Highly Influenced by Social Media since COVID-19 Lockdown}

COVID-19 is a major shock in moving global trends in lifestyle, work routines, and business strategies into the contemporary age, ushering in important changes. COVID-19 serves as a sort of "catalyst" for digitization in work organisation and the workplace, with both positive and negative feedback loops (Amankwah-Amoah et al., 2021; Castillan et al., 2017). Samaritans online in Indian and expatriate communities has increased since the nation is focused on a catastrophe that has impacted millions. In addition to rising healthcare costs, the new nature of COVID-19, the ambiguity surrounding its implementation, and the many implications have created concern and confusion in the general population (Cheng et al., 2021). Having digital meetings organised via social media was correlated with emotions of positivity (Pennington, 2021). The prevalence of social media is seen in a nation with the second-largest smartphone penetration in the world, behind China. As much as $6.8 \%$ 
of the people in China used social media addictively during COVID-19. Social media is an important communication tool for creating, distributing, and consuming information during the beginning of the COVID-19 pandemic (Tsao et al., 2021).

Over the next decade, India is expected to have over 500 million Internet users and over 400 million social media users, who spend an average of about more than two hours on social media each week. Indians especially the youth began expressing their needs and requests for assistance all over social media platforms such as Twitter, Facebook, Instagram, and WhatsApp since the inception of COVID-19. Many individuals were begging for assistance on social media, and many others were providing leads for obtaining these critical services. People immediately took to the initiative, which was started by a few social media celebrities who used their following to obtain the goods they needed. Once the campaign gained traction, social media emerged as an unofficial conduit for optimism in these trying times. Complete strangers were willing to spend their free time making phone calls to organise hospital beds or to check oxygen cylinder lines, even if they did not know them. Many people were ready to travel across many cities in order to give plasma and perhaps save someone's life via the process. Aside from that, individuals and businesses banded together to provide nutritious meals for COVID-19 affected families. Once people learned about online campaigns, organisations of students and young adults emerged to help combat the illness. These volunteer organisations have been formed across the nation and individuals of all age groups work 24 hours a day to provide prompt support. The grave problem the nation was faced with came as a result of everyone joining forces. The volunteer groups verified, authenticated, and uploaded all the new information about hospital beds, oxygen cylinders, and everything else the hospital may have.

Instagram accounts, Twitter handles, WhatsApp groups, and websites devoted to COVID-19 relief began springing up all over the place. Specialized hashtags were developed across platforms in order to make the search process easier. Indians, on the other hand, were not just ready to provide a hand online. Many individuals banded together to contribute money and materials to the battle against the epidemic. In contrast, others set up free services such as oxygen, ambulances, medications, food runs, and other necessities. This time, it was transformed into a massive humanitarian platform for Indians. In addition to the government's assistance, there are a plethora of volunteer groups, organisations, foundations, and people that have played an important role in India's battle against the virus. We applaud each and every individual for their unwavering and unselfish efforts in our battle. Social media platforms were used for reliefs and campaigns and for all sorts of communication since the lockdown brought in a complete halt to offline communication. Meetings and gatherings were moved to the social media handles. This particular study and survey prove hypothesis 1 true since major percentage of respondents gave a response where Indian youth spends more of their time on social media platforms since the pandemic.

\section{Majority of Indian Youth Have an Inclination towards Different Forms Digital Communication Post Pandemic}

Both hypotheses one and two proved true since the majority of Indian youth from various parts of the country had a positive response. Among that the age group ranging from $21-26$ (72 respondents among 84) have inclination to the social media platforms like Facebook, Instagram, and other digital platforms since the pandemic and continue to be the major platforms for communication and other purposes, including shopping and ordering food.

\section{Online Learning-A Major Shift}

Online learning is reported to be widely available, especially in rural and outlying locations. It's a less expensive way to get an education because of the savings on transportation, lodging, and the total expense of going to school. Another intriguing feature of online learning is organizing and arranging one's time to complete online courses. Blended learning and flipped classrooms are the result of integrating face-to-face lectures with technology (Dhawan, 2020). These learning environments have the potential to improve student performance. Students have the flexibility to study whenever and wherever they choose, which leads to the development of new abilities and, ultimately, a desire to learn forever. Teachers and students in the common physical environment of schools are organically linked. Staying up to date on any new changes in the curriculum, setting up the class, becoming involved in extracurricular activities, and any other important information students should know is part of the loop. A study conducted by dentistry students showed that online classroom learning was 
favoured above physical classroom learning. They believed in the benefits of actual classroom examinations, rather than online ones (Yu-Fong Chang et al., 2021).

They have many opportunities to make up for whatever material they missed, since they have close peers, close friends, and knowledgeable instructors they can turn to. This has to do with how we get our information. According to the present findings, students are fighting the worldwide trend of online learning and are also subject to significant levels of psychological stress, which should be addressed by the governments, universities, and educational experts working together (Hossain et al., 2021). However, since it is the only way out and thus most of the Indian youth now accept online learning methods. When we no longer have access to a real place, everything is done online. Covid brought in a situation where learning has shifted entirely to online. Since educational institutions have been shuttered due to the COVID-19 epidemic, the Indian government has encouraged online education to maintain academic continuity. In India, most high-end commercial and governmental institutions have successfully transitioned to online platforms such as Zoom, Google Meet, Microsoft teams, and other similar tools, while many others are still struggling to complete the mammoth job. The difficulties associated with online schooling are many. Majority of youth has shifted the learning process to online/ digital platforms.

\section{Increase in the Use of E-Commerce sites/ Online Shopping}

E-commerce among Indian youth had a moment of inflection during the COVID-19 lockdown and movement restrictions, driving demand to record highs, prompting new consumers and sellers alike to shift to digital platforms, and setting the stage for enduring development for the market's participants. The retail systems driven by digital technology have to be reconfigured rapidly in the face of the COVID-19 epidemic, and this is likely to continue as customers and merchants adjust to new normal conditions (Nanda et al., 2021). Because of the containment measures implemented by the Indian government, millions of Indians have been exposed to online buying, enticing older internet users to increase their online purchasing. The massive use of smartphones and dependable internet allowed ecommerce to take hold beyond urban areas, all the way down to smaller cities and villages. This gave people faith in e-commerce.

A significant change was brought about due to the pandemic: More and more consumers and companies have moved towards online purchasing because of it. While individuals did resort to ecommerce platforms in large numbers this past year during the pandemic, it was mostly because of the increased focus on social distance and safety during the outbreak. Over the last year, many significant consumer developments have taken place, including changes in customer category preferences, the introduction of "new essentials," and the spread of local languages. The insatiable demand for goods and services online during the lockdown and the viral outbreak reflected the many aspects of life during those times. E-tailers said that people suddenly started placing more orders in areas such as groceries, home office supplies, computers, headphones, furniture, consumer electronics, health and fitness, household supplies, personal grooming, clothing, toys, and books. Small and medium companies were able to quickly adapt to the new e-commerce realities when the epidemic hit. A lot of the changes caused by pandemic-triggered adjustments in the e-commerce industry seem permanent.

\section{A Sudden Rise in the Online Food Delivery}

With restaurants dwindling to survive, on-demand food delivery (OFRD) services have lately gained popularity with consumers, especially those who want food and drink delivered to their doorstep (Hong et al., 2021). Food delivery services through the internet have become essential for all market participants to achieve their bottom line, particularly because COVID-19 has changed the thinking of customers (Dsouza \& Sharma, 2021). Many websites provide the online meal ordering and delivery service OFD services. Food delivery firm Kudu, which was founded in 2013, has rolled out contactless dining services to eight other nations across the world, including India. Customers may dine without touching menu cards or talking to the restaurant personnel with Contactless Dining. This increased the use of digital food delivery services in India, especially among the youth.

Restaurants deal with consumers who worry about social distance and personal cleanliness. Contactless Dining also helped to foster the public's faith in doing things after lockdown. Those who use digital devices likely have more home delivery orders after the pandemic due to COVID-19 and the elderly and retired population likely ignore this in most cases and prefer home-cooked food 
(Unnikrishnan \& Figliozzi, 2021). Internet delivery becomes less likely. Users who have selected "eating out" found the contactless payment option more enjoyable. Zomato, one of India's central food delivery App, has been regularly providing its delivery partners with recommendations for basic safety and hygiene guidelines made by the World Health Organization (WHO). When delivery partners get virtual training on conducting contactless delivery, they also receive lessons on virtual interactions and customer service.

Zomato's active delivery partners have supplied washable and reusable face masks and hand sanitizers. Their employees have to pass a flu test every day to show that they are not sick, and thus they must sanitise their masks and bags daily and are not experiencing flu-like symptoms before they $\log$ in each day. In order to increase safety and avoid disputes, Zomato made it possible for customers and restaurants to report their delivery partners for failing to follow safe delivery standards, such as wearing a mask. This created a sense of safety in the minds of Indians, and thus, the usage of food delivery apps increased. Swiggy is another food app that looks into the safety of both delivery partners and their valuable consumers.

\section{Digital Payments - Safer and Easier}

Digital revolution has sped up the use of digital payments in India, and it was further moved with the onset of Covid-19. Customers may have fewer obstacles in the way of digital payments, but they still may suffer financial and digital marginalisation (Ying et al., 2020). Despite the dramatic rise in the usage of e -wallets during the COVID-19 epidemic, this is not a voluntary adoption on consumers. When the COVID-19 epidemic is over, there may be a significant drop in eWallet users (Undale et al., 2021). Instead, they should work to enhance the security of e-Wallets. Indian Youth have been using e-wallets like google pay, phone pay etc. to a great extent. Now that we anticipate considerable economic growth, digital payment will follow a similar trajectory, at least in the near run (Jain \& Sarupria, 2020). One of the major effects of the epidemic has been to accelerate the country's move away from cash-based payment methods, particularly towards electronic payment methods. An Indian youth was mainly taken away by these digital payments as it is easier and safer, especially during pandemic. Several regular monthly payments were delayed as well as a substantial reduction in expenditure was imposed throughout the lockdown period. During lockdowns, there is considerable ambiguity about important choices. This is major reason for the rise in digital/online payment methods.

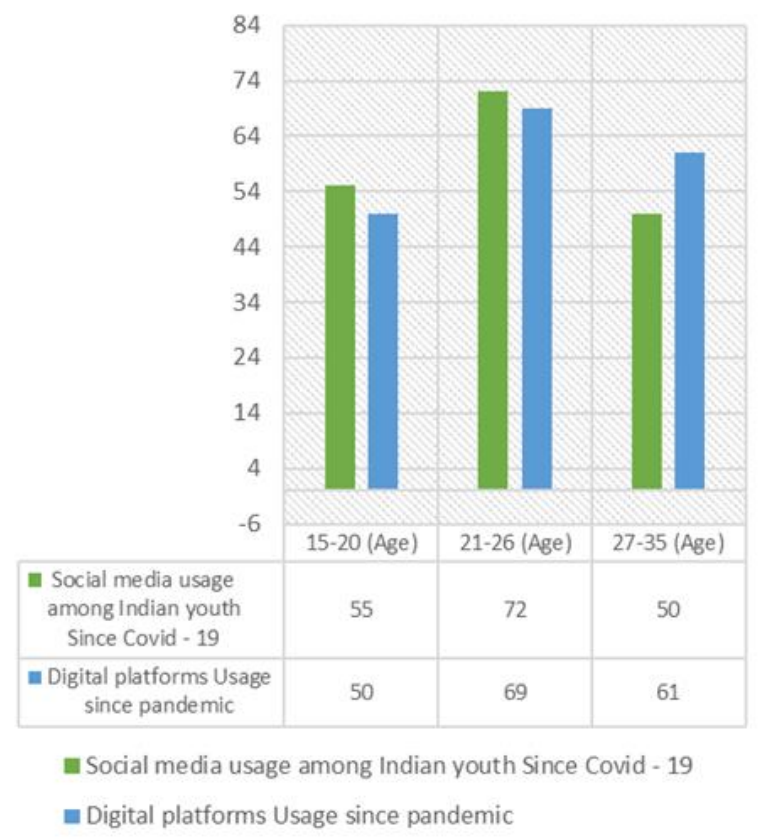

Figure 1. The Impact of Digital/Social Media Platforms among Indian Youth 
The use of ATMs has witnessed a significant drop in since the inception of the pandemic. The recent virus outbreak has prompted people to pile up their money to help them deal with the novel scenario. As the danger of transmission of a virus increases, however, the future use of this expression may be decreased. Limited access to offline shops leads to fewer offline uses of this medium. Furthermore, QR code, Link-based payments, and other forms of contactless payments were chosen since they do not need the transfer of funds through physical touch. Travel and tourism have a large effect on the aggregate volume of digital payments.

\section{Major Percentage among Indian Youth Has Subscribed to the OTT Platforms since the Inception of Pandemic}

This study clearly states that digital platforms influenced most Indian youth, and OTT platforms play an important part. Due to the lockdown, most of the Indian youth are inclined to binge-watching. Age group ranging from 21-26 (44\%) has subscribed to these platforms than the other two age groups mentioned in the study.

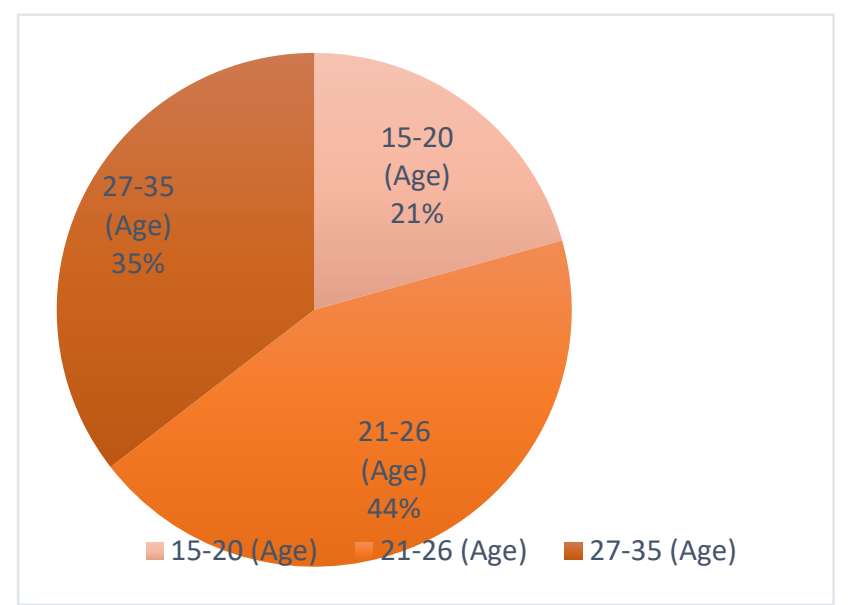

Figure 2. The OTT Platforms Usage Post Pandemic Period

The customer satisfaction levels are inversely proportional to how much room consumers have to watch their families, how much time customers have to utilise the OTT platforms and the quality of the material available on the OTT platforms (Madnani et al., 2020). OTT platforms have accelerated the process of condensing the world's population into a small hamlet. As a result of these platforms, people across the globe have a better knowledge of one another's cultures. When a worldwide epidemic like COVID-19 occurs, video-on-demand services like Netflix and Hulu experience a spike in traffic.(Saini \& Saini, 2020) While most sectors saw a game-changing epidemic, the Covid-19 pandemic revolutionised the entertainment industry. Cinema and theatre closures occurred throughout the majority of the year in 2020, which signals that the next decade would be defined by OTT (overthe-top) entertainment. To keep the film industry running, OTT platforms must be made available. OTT platforms are doing well while multiplexes are losing their ground due of the widespread popularity of OTT viewing (Kaur, n.d.).

People started to spent time in their homes, alone, since they could no longer seek amusement from outside. India is the world's fastest-growing market for OTT service providers, commonly known as streaming platforms. The expansion is predicted to accelerate annually, would soon surpass many other countries. In India, the overall number of Indian Youth who use OTT video streaming services, such as Netflix, Amazon Prime Video, Hotstar Disney+, Zee 5 etc. grew significantly. During the Lockdown, people tended to utilise Online Platforms for amusement rather than television since the latter aired reruns of older or repeat programmes. Since more people are enjoying the alone time and thus OTT subscriptions went up (Sunitha, 2020). As internet streaming audiences outside millennials and metros have increased, as well as those who are not Hindi speakers and non-English speakers, so has the variety of regional streaming applications. Demand for regional material has been high for a number of regional platforms. Among the users' youngsters are more into the OTT platforms for the binge-watch phenomenon. Since the schools and businesses were closed for a long 
time, and the economy is in the dumpster, OTT will be the new normal in the realm of entertainment. It has been very long since certain movie theatres have opened and closed down once again because of the second wave. The only silver lining in all of this is the rising popularity of OTT events, shoots, and premiers.

\section{Learning Apps, Online Gaming and Virtual Reality Have Taken Major Space among the Minds of Indian Youth Post Pandemic}

This hypothesis is proven true again. Digital communication, which includes learning apps, online gaming, and virtual reality, had a huge impact on the Indian youth. Since the inception of Covid-19 pandemic, most of the youth spend most of their time in households the majority started using learning apps, indulging in various online games and virtual reality according to the study. The age group ranging from $15-20(35 \%)$ has major inclination to these digital platforms since the pandemic.

\section{Learning Apps-New Age Learning}

India has seen a greater increase in online learning platforms due to COVID-19. Online learning platforms, like BYJU'S, provide free access to their services due to a substantial increase in demand due to the onset of the pandemic. Lark, an internal tool for exponential development by ByteDance, started providing limitless video conferencing time, intelligent calendar scheduling, and other services to instructors and students. To increase overall worldwide server infrastructure and engineering capabilities in a moment of crisis, Lark stepped up its global server infrastructure and engineering. Indian youth use many other learning apps for training in government sector jobs in many regional languages. Lockdown and boredom made many among the Indian youth incline themselves to such learning apps, which increased the screen time as well.

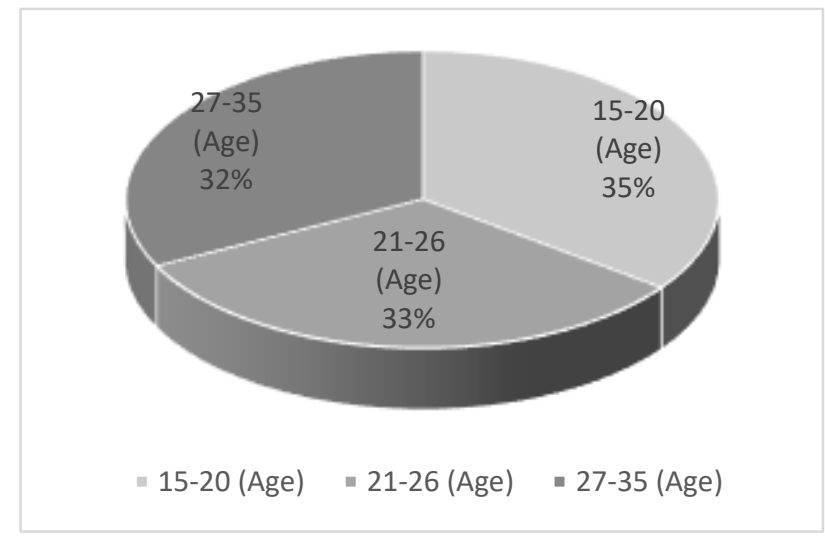

Figure 3. The Influence of Learning Apps and Online Games

\section{Online Gaming-Entertainment at Hand}

Industry experts have said that online games have seen an uptick in popularity after the emergence of COVID-19. With 7.3 billion game installations in the first three quarters of 2020, India is the country with the most rapid growth in mobile gaming. It accounted for more than $15 \%$ of the worldwide total, according to Sensor Tower statistics. Indian gaming is hiking up since people have been homebound for a long time thus may engage in a few leisure activities. In attempts to promote appropriate spatial distance during the epidemic, public health online games played a supportive role (Amin et al., 2020). Today, there are over 300 million online gaming players in India, and most of them belong to the age group below 25. This number is constantly increasing. Industry experts agreed that competitiveness and thrill offered by skill games are comparable to that supplied by real-life sports activities, such as playing football. WinZo Games, a gaming business headquartered in India, has claimed a threefold increase in user engagement and mobile gaming traffic (Raj, 2021). Skill-based games have recently grown popular. Skill-based games have recently grown popular. Skill-based games, mostly played on mobile devices, constitute more than 12 percent of India's total worldwide market share. Like traditional Indian games, a number of popular internet games include ludo, carom, and trivia quiz, which also trace their origins to traditional games. Last, games like this need players to possess 
specific levels of dexterity, knowledge, and ability to use their minds to succeed. Extended lockdown and pandemic added to the increased use of screentime.

\section{CONCLUSION}

This research study concludes with the major finding on the shift of traditional communication to digital communication in post-pandemic times. The study focused on the Indian youth and digital communication technologies. The researcher examined the growth and use of multiple social networking platforms and their effects on urban Indian youth. A major percentage of more than $70 \%$ were highly receptive to online and digital communication since the pandemic. Most of the respondents use social media platforms to communicate since traditional communication has been on a halt. Covid brought in a situation where learning has shifted completely to online. Since educational institutions have been shuttered due to the COVID-19 epidemic, the Indian government has encouraged online education to maintain academic continuity. While determining the effects created by OTT platforms, more than $60 \%$ of respondents have already subscribed to any of the major OTT platforms. Researcher finds out the impact of Virtual Reality, Learning Apps, and online gaming have gone through a major shift where the respondents have high regard and positive response to the technology of online gaming along with communication, interactive learning apps, and virtual reality. Indian Youth from all the age groups ranging from 15 - 20, 21- 26, and 27 -35 were found highly inclined to the digital platforms for various purposes, including online learning, e-commerce, food delivery apps, digital payments, learning apps, online games, virtual reality, etc.

E-commerce among Indian youth had a moment of inflection during the COVID-19 lockdown and movement restrictions, driving demand to record highs, prompting new consumers and sellers alike to shift to digital platforms, and setting the stage for enduring development for the market's participants. Then, most high-end commercial and governmental institutions have successfully transitioned to online platforms such as Zoom, Google Meet, Microsoft teams, and other similar tools, while many others are still struggling to complete the mammoth job. Furthermore, QR codes, Link-based payments, and other forms of contactless payments were chosen since they do not need the transfer of funds through physical touch. Travel and tourism have a significant effect on the aggregate volume of digital payments. Last, there are over 300 million online gaming players in India, and most of them belong to the age group below 25 . This number is constantly increasing. Industry experts agreed that competitiveness and thrill offered by skill games are comparable to that supplied by real-life sports activities, such as playing football. WinZo Games, a gaming business headquartered in India, has claimed a threefold increase in user engagement and mobile gaming traffic.

\section{REFERENCES}

Abdel-Basset, M., Chang, V., \& Nabeeh, N. A. (2021). An intelligent framework using disruptive technologies for COVID-19 analysis. Technological Forecasting and Social Change, 163, 120431. https://doi.org/10.1016/j.techfore.2020.120431

Amankwah-Amoah, J., Khan, Z., Wood, G., \& Knight, G. (2021). COVID-19 and digitalization: The great acceleration. Journal of Business Research, 136, 602-611. https://doi.org/10.1016/J.JBUSRES.2021.08.011

Amin, K. P., Griffiths, M. D., \& Dsouza, D. D. (2020). Online Gaming During the COVID-19 Pandemic in India : Strategies for Work-Life Balance.

Büscher, B., Feola, G., Fischer, A., Fletcher, R., Gerber, J. F., Harcourt, W., Koster, M., Schneider, M., Scholtens, J., Spierenburg, M., Walstra, V., \& Wiskerke, H. (2021). Planning for a world beyond COVID-19: Five pillars for post-neoliberal development. World Development, 140, 105357. https://doi.org/10.1016/j.worlddev.2020.105357

Castillan, L., Chheang, C., Denoux, C., Ferrenbach, C., Gérard, C., Hua, E., Van Holt, J., \& Coste Manière, I. (2017). Online luxury: The code breakers of a traditional sector. Procedia Computer Science, 122, 579-586. https://doi.org/10.1016/j.procs.2017.11.409

Cheng, S. F., Kuo, C. L., Lee, C. C., Wei, S. H. M., \& Huang, C. Y. (2021). Empowering the public during the COVID pandemic through interactive social media platform. Nursing Outlook. https://doi.org/10.1016/J.OUTLOOK.2021.04.002 
Dhawan, S. (2020). Online Learning: A Panacea in the Time of COVID-19 Crisis. https://doi.org/10.1177/0047239520934018

Dsouza, D., \& Sharma, D. (2021). Online food delivery portals during COVID-19 times: an analysis of changing consumer behavior and expectations. International Journal of Innovation Science, 13(2), 218-232. https://doi.org/10.1108/IJIS-10-2020-0184

Echegaray, F. (2021). What POST-COVID-19 lifestyles may look like? Identifying scenarios and their implications for sustainability. In Sustainable Production and Consumption (Vol. 27, pp. 567-574). Elsevier B.V. https://doi.org/10.1016/j.spc.2021.01.025

Grapsa, J. (2020). Post-COVID-19 Lessons. JACC: Case Reports, 2(11), 1833-1834. https://doi.org/10.1016/j.jaccas.2020.08.001

Hong, C., Choi, H. (Hailey), Choi, E.-K. (Cindy), \& Joung, H.-W. (David). (2021). Factors affecting customer intention to use online food delivery services before and during the COVID-19 pandemic. Journal of Hospitality and Tourism Management, 48, 509-518. https://doi.org/10.1016/J.JHTM.2021.08.012

Horgan, D., Hackett, J., Westphalen, C. B., Kalra, D., Richer, E., Romao, M., Andreu, A. L., Lal, J. A., Bernini, C., Tumiene, B., \& Boccia, S. (2020). Digitalisation and COVID-19: The Perfect Storm. https://doi.org/10.1159/000511232

Hossain, M. J., Ahmmed, F., Rahman, S. M. A., Sanam, S., Emran, T. Bin, \& Mitra, S. (2021). Impact of online education on fear of academic delay and psychological distress among university students following one year of COVID-19 outbreak in Bangladesh. Heliyon, 7(6), e07388. https://doi.org/10.1016/J.HELIYON.2021.E07388

Iivari, N., Sharma, S., \& Ventä-Olkkonen, L. (2020). Digital transformation of everyday life - How COVID-19 pandemic transformed the basic education of the young generation and why information management research should care? International Journal of Information Management, 55, 102183. https://doi.org/10.1016/j.ijinfomgt.2020.102183

Itzchakov, G., \& Grau, J. (2020). High-quality listening in the age of COVID-19: A Key to better dyadic communication for more effective organizations. Organizational Dynamics, 100820. https://doi.org/10.1016/j.orgdyn.2020.100820

Jain, A., \& Sarupria, A. (2020). The Impact of COVID-19 on E-wallet's Payments in Indian Economy. June. https://doi.org/10.13140/RG.2.2.13584.02562

Jamalpur, B., Kafila, Chythanya, K. R., \& Kumar, K. S. (2021). A Comprehensive Overview of Online Education - Impact on Engineering Students during COVID-19. Materials Today: Proceedings. https://doi.org/10.1016/j.matpr.2021.01.749

Kaur, N. (n.d.). Fighting COVID-19 with technology and innovation, evolving and advancing with technological possibilities AND INNOVATION , EVOLVING AND. https://doi.org/10.34218/IJARET.11.7.2020.039

Kencana, W., \& Meisyanti, M. (2020). The Implementation of Mass Media Digital Platform in Indonesia. Komunikator, 12(2), 90-105. doi: https://doi.org/10.18196/jkm.122038

Madnani, D., Fernandes, S., \& Madnani, N. (2020). Analysing the impact of COVID-19 on over-thetop media platforms in India. International Journal of Pervasive Computing and Communications, 16(5), 457-475. https://doi.org/10.1108/IJPCC-07-2020-0083

Nanda, A., Xu, Y., \& Zhang, F. (2021). How would the COVID-19 pandemic reshape retail real estate and high streets through acceleration of E-commerce and digitalization? Journal of Urban Management, 10(2), 110-124. https://doi.org/10.1016/J.JUM.2021.04.001

Naryoso, A., Febriyani, A., \& Kaloka, R. (2021). Digital Campaign to Reduce Covid-19 Pandemic Risk. Komunikator, 13(1), 1-14. doi: https://doi.org/10.18196/jkm.131046

Pennington, N. (2021). Communication outside of the home through social media during COVID-19. $\begin{array}{llll}\text { Computers in Human Behavior Reports, } & \text { 4, }\end{array}$ https://doi.org/10.1016/J.CHBR.2021.100118

Raj, M. A. (2021). A Study On Digital Gaming Behavior And Its Associations With COVID-19 Pandemic. June.

Saini, N., \& Saini, N. (2020). USAGE OF OTT PLATFORMS DURING COVID-19 LOCKDOWN : TRENDS , . 17(6), 4212-4222.

Shao, G. (2009). Understanding the appeal of user-generated media: a uses and gratification perspective. Internet Research, 19(1), 7-25. https://doi.org/10.1108/10662240910927795

Sunitha, S. (2020). Covid-19 Conclusion : A Media And Entertainment Sector Perspective In India Covid-19 Conclusion : A Media And Entertainment Sector Perspective In India. October. 
Vol. 13 No. 2

Tsao, S. F., Chen, H., Tisseverasinghe, T., Yang, Y., Li, L., \& Butt, Z. A. (2021). What social media told us in the time of COVID-19: a scoping review. In The Lancet Digital Health (Vol. 3, Issue 3, pp. e175-e194). Elsevier Ltd. https://doi.org/10.1016/S2589-7500(20)30315-0

Undale, S., Kulkarni, A., \& Patil, H. (2021). Perceived eWallet security: impact of COVID-19 pandemic. Vilakshan - XIMB Journal of Management, 18(1), 89-104. https://doi.org/10.1108/XJM-07-2020-0022

Unnikrishnan, A., \& Figliozzi, M. (2021). Exploratory analysis of factors affecting levels of home deliveries before, during, and post- COVID-19. Transportation Research Interdisciplinary Perspectives, 10, 100402. https://doi.org/10.1016/J.TRIP.2021.100402

Ying, B., Toh, L., \& Tran, T. (2020). How the COVID-19 Pandemic May Reshape the Digital Payments Landscape. 1-10.

Yu-Fong Chang, J., Wang, L. H., Lin, T. C., Cheng, F. C., \& Chiang, C. P. (2021). Comparison of learning effectiveness between physical classroom and online learning for dental education during the COVID-19 pandemic. Journal of Dental Sciences, 16(4), 1281-1289. https://doi.org/10.1016/J.JDS.2021.07.016 